\title{
Translation Studies and Corpus Linguistics: Introducing the Pannonia Corpus
}

\author{
Edina ROBIN, Andrea GÖTZ, Éva PATAKY, \\ Henriette SZEGH \\ ELTE (Budapest, Hungary) \\ Department of Translation Studies \\ pannonia.corpus@gmail.com
}

\begin{abstract}
The tools of corpus linguistics have become indispensable for research in descriptive translation studies (DTS), which aims to describe the characteristics of the translation process, and translational texts. Machinereadable corpora of translated texts are crucially important since they can yield statistically significant results that underpin the findings of empirical studies. Baker's (1993) seminal paper gave new impetus to translation research as it has re-calibrated the goals of DTS to study and uncover the particular properties of the so-called "third code" (Frawley 1984), i.e. the language of translated texts, with the help of computerized corpora. The present study, after providing a brief overview of international and Hungarian corpus linguistic research, introduces the Pannonia Corpus Project developed by Eötvös Loránd University's Translation Studies Doctoral Programme, which was created to make a Hungarian translation corpus, containing millions of words, available for translation researchers. The Pannonia Corpus (PC) is a multi-modal corpus: it contains translated, interpreted, and audiovisual texts. It represents a diverse array of texts of specialized and literary genres, reflecting modern language use and the current state of the translation industry. The PC provides researchers with a vital opportunity as its multimodality, diverse textual make-up, and substantial size are unparalleled in the Hungarian context. Until now, there were no large corpora available to researchers that could have facilitated qualitative as well as quantitative research, satisfying the demands of modern translation studies research in Hungary.
\end{abstract}

Keywords: corpus linguistics, translation corpus, parallel, comparable, corpus research 


\section{Translation studies and corpus research}

All knowledge in the world, not formulated in one's native language, may only be accessed through language mediation, i.e. translation. Therefore, it is not tenable to treat translations as the defective, inferior products of secondary communication, unworthy of scientific research in their own right (Baker 1993). Empirically based, descriptive translation studies disregards all such views; however, it does not deny the differences between translated and non-translated texts. One concept capturing this difference is the so-called third code (Frawley 1984). The idea of the third code states that the language of translations differs from both the code of source text and that of the target text, despite being created under the influence of both (Frawley 1984: 168). Therefore, the task of translation researchers is to explore the nature of these differences and to examine the universal characteristics of the translational text (Károly 2007).

For descriptive translation studies, which aims to explore the specific general features of translated as well as interpreted language, it is essential to study the translated texts for their own sake. Furthermore, it is also vital to compare translated with authentic, i.e. non-translated texts, as espoused by Baker (1993), in order to fully account for the universal tendencies of translated texts, which emerge when compared to authentic texts. Baker in her seminal paper (1993) named three types of corpora that can be useful for both translation studies and translator training: 1) parallel corpora, suitable for studying and teaching translational behaviour, translation strategies; 2) monolingual comparable corpora, which accommodate the comparison of translated and non-translated texts; and, finally, 3) multilingual corpora, which facilitate investigations of lexicography with a view to equivalence.

Responding to Baker's (1996) call for the use of corpora in translation studies, research projects were set up in many countries around the world to compile parallel and comparable corpora in order to provide statistically significant empirical findings to test the hypotheses formulated about the universal features of the translational text. The spread of computer-readable electronic corpora, facilitating automatic queries, allowed for corpus-based methods to be applied to the examination of translated texts. This means that through these analyses it is possible to uncover the universal linguistic patterns hypothesised to be specific to translations, thus establishing the research area of corpus-based translation studies (CTS). To date, many corpora have been compiled, even exceeding the three basic corpus types set up by Baker (1996). These new types can contain bilingual components, creating bidirectional parallel corpora, also suitable for comparable text analyses, or translated and interpreted components in interpretational and intermodal corpora, the latter containing texts from both 
written and spoken discourse, as well as audiovisual texts, catering for the needs of one of the latest trends in translation research.

Despite the wide use of corpus-based methods in translation research, no corpus, comprising millions of words, has been compiled in Hungary that would allow for the corpus-based study of a wide range of translational activities. To date, all translational Hungarian corpora have been self-assembled and relatively small, designed for the specific aims of the given research (Pápai 2001, Seidl-Péch 2011, Robin 2015). Klaudy (2012) notes how unfortunate it is that, despite numerous previous calls for deploying corpora in translator training (e.g. Kohn 1999), a large Hungarian translational corpus has yet to be compiled and made available to a wide community of translation scholars. Ideally, in order to be representative of the Hungarian translation industry, such a corpus would contain both literary and technical texts. Bringing corpus-based approaches to Hungarian translation studies would benefit both the practice and theory of translation. Significant results derived from a representative corpus could offer more valid information that is rooted in empirical evidence on translation strategies to translators. Similarly, by identifying tendencies, rules, and regularities of Hungarian language use, translation studies could contribute to the development of the Hungarian language (Klaudy 2001).

\section{Corpus research in Hungarian translation studies}

Pápai (2004) was the first to perform automated analyses on a Hungarian-English parallel and a Hungarian comparable corpus (Arrabona Corpus), examining explicitation in Hungarian translated texts. She compared translations of fiction and sociological texts with the source language originals and comparable authentic texts, examining their type-token ratio and lexical variability. The results of the statistical analysis supported Laviosa's previous results (1998, 2000), as Pápai found a lower type-token ratio in translations than in original texts, meaning that translated texts show less lexical variability. Pápai (2004: 160) concluded that there is a strong relationship between simplification and explicitation: explicitating shifts inevitably lead to an increase in the number of words and lexical repetition - for example, addition of connectives, pronouns, and cataphoric references -, giving rise to less varied vocabulary in translated texts.

Seidl-Péch (2011) similarly examined a self-compiled and annotated translational corpus composed of four sub-corpora, including public, fictional, religious, and scientific texts. She demonstrated cohesive shifts in translated texts through lexico-grammatical analyses. The analyses explore the typical lexical features of authentic and translated Hungarian texts. The corpus only contains texts which are in the public domain, thereby avoiding any copyright problems. The research 
shows that original and translated texts differ in terms of the use of cohesive devices, which means that the cohesive patterns of translated Hungarian can be traced back to the effects of translation. Furthermore, the research brought a significant result by proving that the examination of cohesive shifts can be automated with tools of corpus linguistics (WordNet).

While examining translation universals in revised texts, Robin (2015) performed general statistical machine analyses on a revisional corpus consisting of the translated and revised versions of ten English language novels. Later on, she compared the results with the statistical data of ten novels originally written in Hungarian (2016). The average length of sentences, differences between typetoken ratios, lexical frequency profiles, lexical density, and the standard deviation of data were examined. From the results, it may be assumed that revisers - whose task is to revise translations and fine-tune them in accordance with the target language norms - perform a significant amount of operations, thereby creating more explicit and less redundant texts with a richer vocabulary. In the majority of cases, due to revisional operations, the features of translated texts seem to approximate those of authentic texts, i.e. the norms of the target language. At the same time, some universal editing strategies may be observed, typical of revision.

Table 1. Translation corpora in Hungarian translation studies

\begin{tabular}{|c|c|c|c|c|c|}
\hline & $\begin{array}{l}\text { Pápai } \\
\text { (2001) }\end{array}$ & $\begin{array}{l}\text { Heltai } \\
(2007)\end{array}$ & $\begin{array}{l}\text { Szabó } \\
(2011)\end{array}$ & $\begin{array}{l}\text { Seidl-Péch } \\
\text { (2011) }\end{array}$ & $\begin{array}{l}\text { Robin } \\
(2015)\end{array}$ \\
\hline $\begin{array}{l}\text { Name of the } \\
\text { corpus: }\end{array}$ & $\begin{array}{l}\text { Arrabona } \\
\text { Corpus }\end{array}$ & & HunOr & $\begin{array}{l}\text { Hungarian } \\
\text { Lexical } \\
\text { Cohesion } \\
\text { Project }\end{array}$ & \\
\hline Type: & $\begin{array}{l}\text { parallel and } \\
\text { comparable }\end{array}$ & parallel & $\begin{array}{l}\text { parallel, } \\
\text { bidirectional }\end{array}$ & comparable & $\begin{array}{l}\text { parallel, } \\
\text { revisional }\end{array}$ \\
\hline $\begin{array}{l}\text { Size } \\
\text { (number of } \\
\text { words): }\end{array}$ & $\begin{array}{l}2,400 \\
\text { sentences, } \\
45,000 \text { words }\end{array}$ & $\begin{array}{l}1.1 \text { million } \\
\text { words }\end{array}$ & $\begin{array}{l}130,000 \\
\text { words }\end{array}$ & $\begin{array}{l}4 \text { million } \\
\text { words }\end{array}$ & $\begin{array}{l}2.8 \text { million } \\
\text { words }\end{array}$ \\
\hline Languages: & $\begin{array}{l}\text { English- } \\
\text { Hungarian; } \\
\text { Hungarian }\end{array}$ & $\begin{array}{l}\text { English- } \\
\text { Hungarian }\end{array}$ & $\begin{array}{l}\text { Russian- } \\
\text { Hungarian, } \\
\text { Hungarian- } \\
\text { Russian }\end{array}$ & $\begin{array}{l}\text { Hungarian- } \\
\text { Hungarian }\end{array}$ & $\begin{array}{l}\text { English- } \\
\text { Hungarian }\end{array}$ \\
\hline $\begin{array}{l}\text { Annotated/ } \\
\text { Metadata/ } \\
\text { Type: }\end{array}$ & $\begin{array}{l}\text { no/ } \\
\text { yes }\end{array}$ & $\begin{array}{l}\text { yes/ } \\
\text { yes/ } \\
\text { POS-tagging, } \\
\text { headers }\end{array}$ & $\begin{array}{l}\text { yes/ } \\
\text { yes }\end{array}$ & $\begin{array}{l}\text { yes/ } \\
\text { partly/ } \\
\text { WordNet }\end{array}$ & $\begin{array}{l}\text { no/ } \\
\text { yes }\end{array}$ \\
\hline
\end{tabular}




\begin{tabular}{|c|c|c|c|c|c|}
\hline & $\begin{array}{l}\text { Pápai } \\
\text { (2001) }\end{array}$ & $\begin{array}{l}\text { Heltai } \\
(2007)\end{array}$ & $\begin{array}{l}\text { Szabó } \\
\text { (2011) }\end{array}$ & $\begin{array}{l}\text { Seidl-Péch } \\
\text { (2011) }\end{array}$ & $\begin{array}{l}\text { Robin } \\
\text { (2015) }\end{array}$ \\
\hline $\begin{array}{l}\text { Text types/ } \\
\text { Sub- } \\
\text { corpora: }\end{array}$ & $\begin{array}{l}\text { fiction and } \\
\text { scientific } \\
\text { prose }\end{array}$ & $\begin{array}{l}\text { technical texts/ } \\
\text { economy, } \\
\text { agriculture, } \\
\text { environmental } \\
\text { protection, EU } \\
\text { texts, science, } \\
\text { biology, human } \\
\text { sciences }\end{array}$ & $\begin{array}{l}\text { fiction, } \\
\text { scientific, } \\
\text { official }\end{array}$ & $\begin{array}{l}4 \text { sub-corpora } \\
\text { public (EU), } \\
\text { fiction, } \\
\text { scientific, } \\
\text { religious }\end{array}$ & $\begin{array}{l}\text { popular } \\
\text { literature } \\
3 \text { sub-corpora } \\
\text { original, } \\
\text { translated, } \\
\text { revised }\end{array}$ \\
\hline $\begin{array}{l}\text { Date of } \\
\text { publication: }\end{array}$ & & $\begin{array}{l}\text { 1970-2008 } \\
\text { (sub-corpus } \\
2002-2008 \text { ) }\end{array}$ & & & after 2000 \\
\hline Other: & $\begin{array}{l}\text { The first one } \\
\text { hundred } \\
\text { sentences of } \\
\text { each work. } \\
\text { Each of the } \\
\text { sub-corpora } \\
\text { contains } \\
8 \text { works } \\
\text { (original- } \\
\text { translated- } \\
\text { comparable). }\end{array}$ & $\begin{array}{l}\text { Complete texts. } \\
\text { The } \\
\text { complementary } \\
\text { corpus contains } \\
105 \text { texts of } \\
4,000-5,000 \\
\text { words (these } \\
\text { are translations } \\
\text { of students of } \\
\text { translation), } \\
\text { this sub-corpus } \\
\text { contains } 630,000 \\
\text { words. }\end{array}$ & $\begin{array}{l}\text { Complete } \\
\text { texts }\end{array}$ & $\begin{array}{l}\text { Only publicly } \\
\text { available texts } \\
\text { have been } \\
\text { collected (in } \\
\text { order to avoid } \\
\text { copyright } \\
\text { problems). }\end{array}$ & $\begin{array}{l}10 \text { pairs of } \\
\text { translator- } \\
\text { proofreader. } \\
\text { Quantitative } \\
\text { and qualitative } \\
\text { methods. } \\
\text { Categorization } \\
\text { of grammatical } \\
\text { and lexical } \\
\text { transfer } \\
\text { operations } \\
\text { based on exp. } \\
\text { and imp. }\end{array}$ \\
\hline
\end{tabular}

Only corpora compiled individually and with a predefined research goal served as the basis of the aforementioned examinations. The characteristics of these corpora are summarized in Table 1. In Hungary, there have not been any corpora similar to the English TEC or the Finnish CTF, which could be utilized for a wide range of purposes, nor any corpora containing translations which could give a representative overview of translation activities. The Language Institute of Szent István University started to build a parallel corpus of technical texts in 2001, which was the first project of its kind in Hungary (Heltai 2007). The project aimed at using the results of corpus research in translator training. Prior to compiling the corpus, the research group had defined the fields where texts should be collected from in order to cover a range of translation activities as wide as possible. Also, the texts were categorized according to their level of translation quality. It was regarded as a novelty that the corpus contained not only translations from professional translators but translations of university students as well, providing an opportunity to examine translation quality and competence. Unfortunately, the project was advancing very slowly with building 
the corpus; then the process got halted partly because of technical reasons, partly due to the difficulties of collecting translated texts; the research group did not achieve their goal as the corpus remained unfinished and inaccessible for researchers. Therefore, Hungarian translation studies still remains without a translation corpus which could facilitate a wide range of research goals.

\section{Critical views of corpus-based translation studies}

One of the basic methodological problems pointed out by critics concerns how texts are chosen for a particular corpus (Tymoczko 1998). It is not entirely clear on what criteria one chooses texts to be included in the corpus. What should be considered a translation at all? In what type of texts can phenomena assumed to be universals or can be measured at all? Is it legitimate to ignore differences in quality? Can we assume that the potentially universal characteristics resulting from the research are present in all types of translations? Chesterman (1993) also discussed these questions, and he concluded that general descriptive laws can be set up in connection with any kind of translation, on one condition: the behaviour and its result can be described as translation if a connection can be identified between the source and target texts (cf. Toury 1995, Károly 2007). Chesterman (2010) also emphasized that it is worth paying attention to connections between universals and text quality and also to incorporate a quality variable when compiling the corpora.

Bernardini and Zanettin (2004) questioned the way corpora were compiled. They criticized the usage of monolingual comparable corpora. Such corpora became very popular since examining exclusively the target texts excludes bias originating from the source texts. However, they raised the questions of comparability and opposed the idea of ignoring the source texts. They argued that if one intends to compare the characteristics of a translation corpus with that of a corpus originally written in the target language, then it is also necessary to examine the status of the source language text, using a corpus compiled from texts which were originally written in the source language.

Pym (2008) also laments the exclusion of the source language texts, mainly in connection with Baker's (1995) corpus research, arguing that monolingual, comparable corpora are not sufficient when it comes to accounting for interference affecting translation; therefore, conclusions drawn from research using such corpora cannot be deemed as valid and/or universal. Becher (2010) holds similar views in connection with Olohan and Baker (2000), criticizing the "dogma" of the so-called translation-inherent explicitation. His criticism can be generally applied to corpus-based research, similarly to that of several other researchers (Jantunen 2004, Bernardini \& Zanettin 2004). Becher (2010) maintains that 
monolingual translational corpora only suffice for setting up hypotheses and not for providing evidence in themselves.

The debate around corpus data leads back to the conflict between approaches preferring either competence or performance, the fundamental difference of opinion between applied linguistics and generative grammar, based on the fact that the empirical data sourced from corpora might be corrupted as performance unlike competence could be ungrammatical. Corpus research is also criticized because statistical measurements only examine superficial phenomena and do not explore the reasons behind these (Károly 2003: 20). The solution seems to be that quantitative research needs be complemented with qualitative methods (Robin 2015) in order to account for the textual transfer operations causing the patterns identified by quantitative analyses. Furthermore, critics point out how important it is to have comparable data because they provide a point of reference for research results (Saldanha \& O’Brien 2013: 67). For example, frequency can only be meaningfully explored if other benchmarks are known for the frequency of the given item or phenomenon, i.e. comparable data are required to put the frequency measured in a given corpus into perspective.

\section{The Pannonia Corpus Project}

The project was initiated by the researchers of the Translation Studies Doctoral Programme at Eötvös Loránd University with the aim of compiling a so-called mega-corpus of translated Hungarian. Beyond the compilation of this corpus, the project also intends to describe the properties of translation behaviour in general. Such a corpus must be able to accommodate quantitative and qualitative research as well. The compilation of the corpus started within the framework of a doctoral seminar course on translation universals in the spring of 2016. The work has since continued and expanded with the support of the Department of Translation and Interpreting at Eötvös Loránd University, as MA students have been taking part in developing the interpretational and audiovisual sub-corpora.

The research project and the compilation of the Pannonia Corpus has aroused the interest of the Hungarian research community. We have reported on the progress made in the compilation process in various articles and conference papers (Robin et al. 2016; Götz 2016a, 2016b; Robin 2017; Szegh 2016; Robin \& Szegh 2017). Beyond the compilation of the corpus, empirical research is continuously conducted on its texts with regard to the properties of translated and interpreted texts; furthermore, dissertations are under way, based on corpusbased analyses of the collected texts. 


\subsection{The components of the Pannonia Corpus}

The Pannonia Corpus lives up to the standards set for modern-day electronic corpora supporting valid research in translation studies: it is multimodal, meaning that it contains translated, interpreted, and audiovisual texts as well in parallel and comparable components, which allows for studying the varied translation activities of the Hungarian translation industry. The texts of the corpora were chosen to reflect modern Hungarian language use as all translated texts were created after 2000. The aim is to build a translational corpus of tens of millions of words from various text types to ensure that the corpus remains useful for future Hungarian translation research. During the compilation of the texts, we kept in mind all the critical views discussed above concerning the methodology of corpus research (Károly 2003, Bernardini \& Zanettin 2004, Pym 2008), choosing texts (Tymoczko 1998) and the variety of genres (Heltai 2007).

The Pannonia Corpus is made up of a parallel and a comparable component, as shown in Figure 1. The comparable component contains texts written originally in Hungarian, which can be broken down into translational, interpreted, and audiovisual sub-corpora, mirroring the make-up of the parallel corpus, so it may be considered translation dependent (Zanettin 2000). The parallel corpus comprises texts translated into Hungarian, mainly from English, and texts translated from Hungarian. The Pannonia Corpus is a bidirectional corpus as Hungarian texts translated into other languages are also included in the comparable component. It is planned that when the corpus reaches its final size, these texts will comprise half of the main comparable corpus.

The parallel corpus consists of three sub-corpora: translational, interpretational, and audiovisual. The translational corpus contains written, published texts, whereas the interpreting corpus, similar to EPTIC, consists of EP speeches and their transcribed and normalized versions as well as the simultaneously interpreted and translated versions. In this sense, this is rather a pseudo-parallel corpus, like EPTIC, since the written version and the speech of the interpreter cannot be always deemed as strictly parallel, although they are very closely connected. Currently, the interpretational corpus contains only simultaneously interpreted texts though the addition of consecutive interpretation is planned. Similarly to the interpretational, the audiovisual corpus includes the subtitles, the spoken text, and the dubbed versions of movies and television series as well as the original and translated subtitles and the voice-over versions of documentaries.

An important novelty of the parallel corpus is that it contains a number of complementary elements: 1) draft translations of certain translated texts incorporated in the parallel corpus, both from fiction and technical texts; thus, it is possible to build a revisional corpus, enabling the researcher to explore differences of quality between revised versions and draft translations and to 


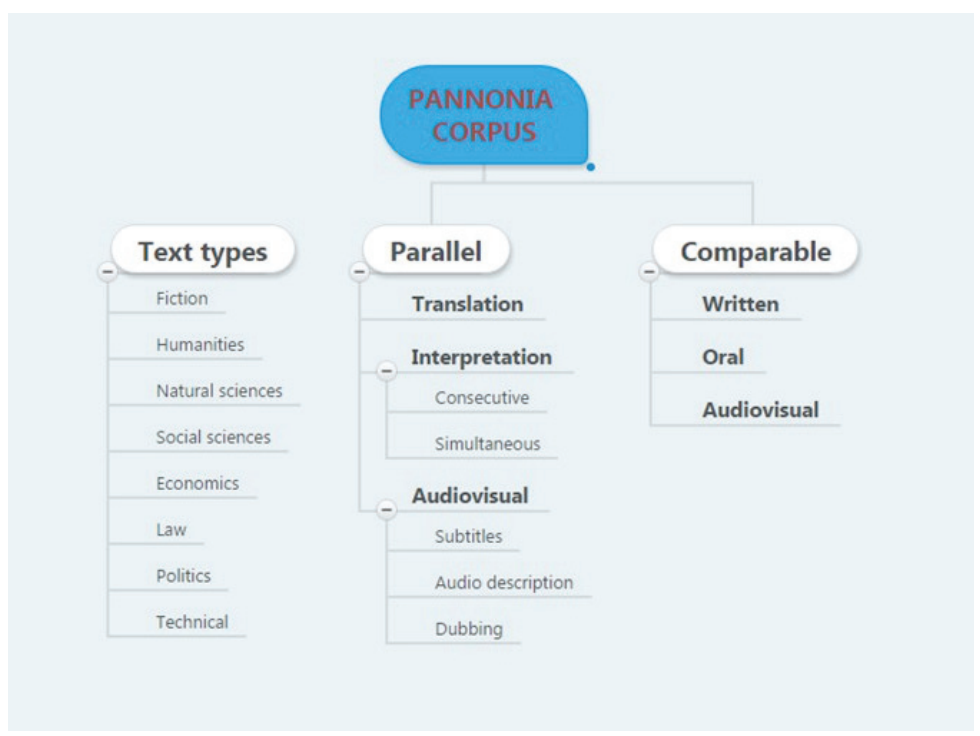

Figure 1. The make-up of the Pannonia Corpus

examine revision as such; 2) the qualifying translations of university students, serving as a complementary didactic corpus, can also be of help when making comparisons of quality or examining translators' competence; hopefully, later on supplemented by interpreted texts as well; 3) previous translations of high literary pieces, created before 2000, are also included, constituting the basis for a retranslational corpus; although the main aim of the project is to represent modern language in translation, the inclusion of re-translated texts opens up the possibility for diachronic research as well. Amongst the audiovisual texts, the researcher may find the work of fan translators, providing even more opportunities for the examination of translation quality.

\subsection{Collection of texts and representativeness}

The technical and complementary, didactic corpus of the Language Institute of Szent István University and Robin’s $(2015,2016)$ revisional and comparable corpora served as an example for our corpus. We have collected texts from the vast amount of texts available on the Internet, and we have contacted different publishers and organizations in order to ask for translations for the Pannonia Corpus to use them - with their consent - for scientific purposes. Although in some cases publishers rejected our request, many publishers and organizations supported the project and provided us with original and translated texts in a digital format. We are grateful to every translator and reviser and the following publishing companies for supporting 
the project with texts: Könyvmolyképző Kiadó, Szak Kiadó, HVG Könyvek, Tempus Közalapítvány, Gondola Kiadó, and Corvin Kiadó.

Table 2. The texts of the Pannonia Corpus according to sub-corpora and text types

\begin{tabular}{|c|c|c|}
\hline \multirow[t]{5}{*}{ Comparable } & humanities-related & 81,971 \\
\hline & business & 27,151 \\
\hline & engineering & 39,084 \\
\hline & popular fiction & 924,994 \\
\hline & social sciences & 166,386 \\
\hline \multicolumn{2}{|l|}{ Comparable - Total } & $1,239,586$ \\
\hline \multirow[t]{9}{*}{ Parallel } & humanities-related & 199,102 \\
\hline & business & 603,251 \\
\hline & legal & 559,715 \\
\hline & engineering & 816,231 \\
\hline & political & 149,723 \\
\hline & literature & $3,630,079$ \\
\hline & popular fiction & $3,819,721$ \\
\hline & social sciences & $1,069,804$ \\
\hline & science & 481,298 \\
\hline \multicolumn{2}{|l|}{ Parallel - Total } & $11,425,130$ \\
\hline \multirow[t]{8}{*}{ Parallel, Comparable } & humanities-related & 50,748 \\
\hline & business & 624 \\
\hline & legal & 148,393 \\
\hline & engineering & 954 \\
\hline & political & 14,929 \\
\hline & literature & 224,659 \\
\hline & popular fiction & 193,394 \\
\hline & science & 30,999 \\
\hline \multicolumn{2}{|c|}{ Parallel, Comparable - Total } & 664,700 \\
\hline \multicolumn{2}{|l|}{ Total } & $13,329,416$ \\
\hline
\end{tabular}

We have also collected original and translated texts publicly available on the Internet, in each case from webpages of organizations that permit the free use of their content if bibliographical data and references are indicated properly, which we have done, too. Among our most important sources are ELTE Reader, Amnesty International, Greenpeace International, the homepage of TED Talks, and the 
database of the European Parliament containing translated and interpreted texts. We have processed the texts of the audiovisual corpus by transcribing the oral texts. In each of the cases, we collected complete texts, books, studies, films, or speeches so that later researchers can decide if they wish to analyse complete texts or only parts of texts. The corpus reflects the work of numerous translators, interpreters and revisers; it consists of altogether 800 text files but does not contain more than 200,000 words from any of the authors.

The aim is to collect texts from as many genres as possible in order to ensure that the corpus appropriately represents the Hungarian translation activities, thereby ensuring representativeness. Table 2 shows the current distribution of the different text types of the corpora, which still needs to be balanced out. Now, the Pannonia Corpus contains approximately 14 million words: almost half of the corpus is made up of technical texts, following the methodological concept according to which research in translation studies must not be limited to fiction (Heltai 2007). The final size is expected to be around 30 million words.

\subsection{Technical background of the corpus}

The corpus is completely digitized. Currently, it is stored in a cloud storage service. The texts can be searched semi-automatically with the help of a spreadsheet, where the researcher can choose from the texts according to their author, title, year of publication, genre, text type, and translator. This helps if the researchers do not want to search the whole corpus but would like to compile their own sub-corpus instead, based on their own criteria. The search result points to a link with an individual code showing the original text as well as its translated or interpreted version.

The documents are accessible in .txt format, and their metainformation is available in files containing separate headers. Table 3 shows what kind of information the headers contain on each text, e.g. the name of the translator, the title of the translation, the type of the translation process, the author's name, and the source text's title.

Furthermore, another document containing the bibliographic data is also part of the corpus. This document ensures the searchability of the texts and the protection of copyrights.

In its current state, the Pannonia Corpus can be analysed manually, semiautomatically, and automatically. The translated and interpreted texts are saved in a .txt format, which can be examined with the help of Wordsmith Tools 6.0, Lex Tutor, and AntConc - all of them are computer-based analysing programs. This way, based on the texts in Pannonia Corpus, it is possible to query lists of frequency, and it is also possible to establish frequency profiles (Xiao et al. 2010) and the type-token ratio, the average length of sentences, and numerous other statistical data can be identified - also for each genre or text type separately. 


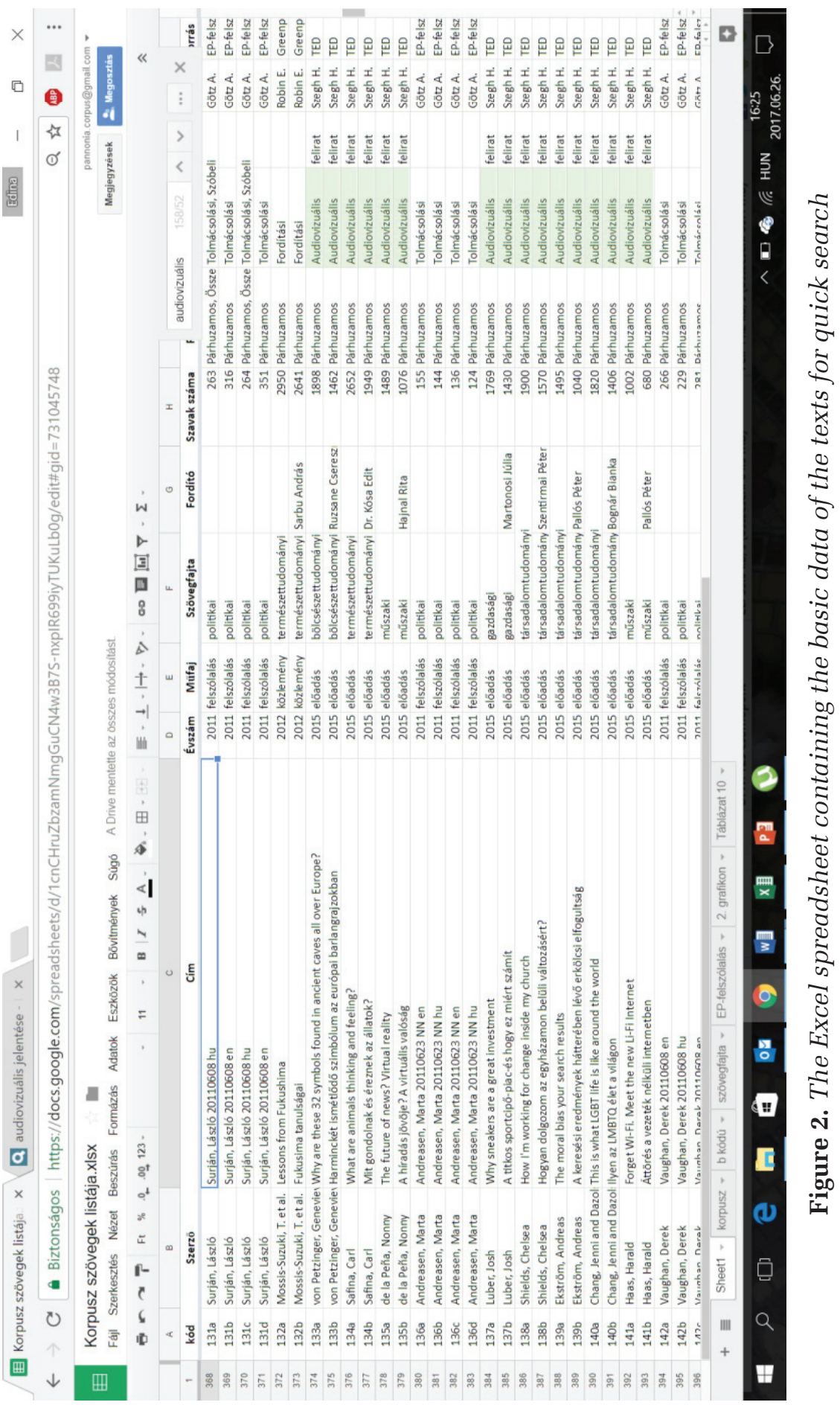


The corpus needs its own website and online storage space, where, beyond storing the details of the texts, an interface would allow for automated searches carried out on the corpus. This could allow researchers to carry out keyword searches on the corpus and its selected components. In the future, the corpus will be automatically annotated, which requires the purchase of a software (POS-tagging, HUMor, WordNet program) and the development of a search interface, which will allow for further linguistic analyses, concordance queries, accommodating analyses of lexicogrammar and cohesion to explore the properties of translated texts - without compromising the availability of qualitative research.

Table 3. Header of the Pannonia Corpus for recording the metainformation of the texts

\begin{tabular}{ll}
\hline TEXT & \\
\hline File name & parallel, comparable, revisional \\
\hline Main corpus & $\begin{array}{l}\text { translation, interpreting, audiovisual, written, } \\
\text { spoken }\end{array}$ \\
\hline Sub-corpus & $\begin{array}{l}\text { spoken, interpreted, normalized, translated, } \\
\text { original, revised, translator's version, retranslated, } \\
\text { original subtitle, translated subtitle, dubbing }\end{array}$ \\
\hline Text type(s) & $\begin{array}{l}\text { fiction, entertaining literature, human sciences, } \\
\text { natural sciences, social sciences, economic, legal, } \\
\text { political, technical }\end{array}$ \\
\hline Genre of the text & \\
\hline TRANSLATOR & \\
\hline Name & \\
\hline Sex & professional, student, volunteer \\
\hline Nationality & \\
\hline Competence & \\
\hline TRANSLATION & \\
\hline Translation's title & \\
\hline Target language & \\
\hline Qualification & \\
\hline Publisher & \\
\hline Place of publication & \\
\hline Year of publication & \\
\hline Direction & \\
\hline Type & \\
\hline
\end{tabular}




\begin{tabular}{ll}
\hline Revision & revised, translator's version \\
\hline CAT-tool & memoQ, Trados, Google \\
\hline Project & group or individual work \\
\hline AUTHOR & \\
\hline Name & native, non-native \\
\hline Sex & \\
\hline Nationality & \\
\hline SOUmand of the language & \begin{tabular}{l} 
\\
\hline Original title
\end{tabular} \\
\hline Source language & $\begin{array}{l}\text { declaration, informative text, contract, } \\
\text { presentation, speech, TV series, movie, an act of }\end{array}$ \\
\hline Genre & \\
\hline Publisher & \\
\hline Place of publication & EP, TED, Amnesty, EU, etc. \\
\hline Year of publication & \\
\hline NOTE & \\
\hline
\end{tabular}

\section{Conclusions and research possibilities}

The work in the present research project has two goals: corpus compilation and corpus-based research. Work on the Pannonia Corpus has just started; nevertheless, its size with nearly 14 million words is already substantial. Its final size is planned to reach 30 million words. As shown in Table 1, the number of texts in certain text types needs to be balanced out. Primarily, additional legal, political, humanitiesrelated, and science texts are needed. The comparable component of the corpus requires further work as all text types require additional texts. The wider research community can only be granted access to the corpus after it has been balanced out. In the future, individual researchers will be granted access to the corpus after having signed the terms and conditions regarding the copyright and appropriate use of the texts. Access will be granted by the lead researcher of the project or the Head of the Translation and Interpreting Doctoral Programme at Eötvös Loránd University. ${ }^{1}$

The Pannonia Corpus is a multimodal, parallel, comparable corpus, specifically established for the purposes of translation research. As set out among the

1 For access and further inquiries: pannonia.corpus@gmail.com. 
objectives of the project, the corpus will soon be accessible for all researchers of translation studies to examine translated texts. The corpus can be combined with other corpora for individual purposes (e.g. Götz 2016b) in order to further enrich our knowledge on translation, and it can be used for compiling education material in translator training. Although the development of Pannonia Corpus is not completed, it supports a plethora of examination in its current state. For example, analyses can already be carried out on translated, interpreted, and audiovisual texts, as well as for intermodal comparisons. In addition, textual operations of translation and interpretation can be investigated, and operations of literary as opposed to technical translation can also be contrasted. Furthermore, the effect of editing can be investigated in terms of the effect of editorial operations on translated texts - not only in literary but also in technical translations as well, in multiple text types. Universals of translation and interpreting can be further explored in relation to the Hungarian language as well as other concepts of translation research such as the re-translation hypothesis.

\section{Acknowledgements}

We are grateful to Professor Kinga Klaudy, Head of the Translation Studies Doctoral Programme for providing us with the opportunity to start the work on the corpus within the programme's framework. Furthermore, we would like to thank Dr Ildikó Horváth for giving us support by making it possible for us to involve the MA students at the Department of Translator and Interpreter Training.

\section{References}

Baker, Mona. 1993. Corpus linguistics and translation studies: implications and applications. In: Baker, Mona-Francis, Gill-Tognini-Bonelli, Elena (eds), Text and technology: in honour of John Sinclair. Amsterdam/Philadelphia: Benjamins. 233-250.

1995. Corpora in translation studies. An overview and suggestion for future research. Target 7(2): 223-245.

Becher, Viktor. 2010. Abandoning the notion of 'translation-inherent' explicitation. Against a dogma of translation studies. Across Languages and Cultures 11(1): $1-28$.

Bernardini, Silvia-Ferraresi, Adriano-Miličević, Maja. 2016. From EPIC to EPTIC. Exploring simplification in interpreting and translation from an intermodal perspective. Target 28(1): 58-83. 
Bernardini, Silvia-Zanettin, Federico. 2004. When is a universal not a universal? Some limits of current corpus-based methodologies for the investigation of translation universals. In: Mauranen, Anna-Kujamaki, Pekka (eds), Translation universals: do they exist? Amsterdam: Benjamins. 51-62.

Chesterman, Andrew. 1993. From "is" to "ought": Laws, norms and strategies in translation studies. Target 5(1): 1-20.

2004. Beyond the particular. In: Mauranen, Anna-Kujamaki, Pekka (eds), Translation universals: do they exist? Amsterdam: Benjamins. 33-49.

2010. Why study translation universals? In: Hartama-Heinonen, Ritva-Kukkonen, Pirjo (eds), Kiasm. Acta Translatologica Helsingiensia 1: 38-48. Helsinki: Helda.

Dam, Helle Vronning. 2010. Consecutive interpreting. In: Gambier, Yves-van Doorslaer, Luc (eds), Handbook of translation studies 1. Amsterdam: John Benjamins Publishing Company. 75-79.

Eskola, Sari. 2004. Untypical frequencies in translated language: a corpusbased study on a literary corpus of translated and non-translated Finnish. In: Mauranen, Anna-Kujamaki, Pekka (eds), Translation universals: do they exist? Amsterdam: Benjamins. 83-97.

Frawley, William. 1984. Translation: literary, linguistic and philosophical perspectives. Delaware: University of Delaware Press.

Götz, Andrea. 2016a. Az intermodális tolmácsolási korpusz felépítése és kutatási lehetőségei. Elhangzott: A Papp Ferenc Baráti Kör Találkozója. Budapest, ELTE BTK FTT. (19 december 2016).

2016b. Vajon in translated Hungarian. Diverging patterns in two fiction genres. Acta Universitatis Sapientiae, Philologica 8(3): 31-41.

Heltai, Pál. 2007. Párhuzamos szaknyelvi korpusz munkálatai a Szent István Egyetemen. In: Feketéné Silye, Magdolna (ed.), Porta Lingua. Debrecen: DE ATC. 285-293.

Károly, Krisztina. 2003. Korpusznyelvészet és fordításkutatás. Fordítástudomány $5(2)$.

2007. Szövegtan és fordítás. Budapest: Akadémiai Kiadó.

Kenny, Dorothy. 2000. Lexical hide-and-seek: looking for creativity in a parallel corpus. In: Olohan, Maeve (ed.), Intercultural faultlines. Research models in translation studies I: Textual and cognitive aspects. Amsterdam: St. Jerome. 93-103.

Kohn, János. 1999. Párhuzamos szövegek számítógéppel segített elemzése a fordításoktatásban (1. rész). Fordítástudomány 1(1): 67-78.

2000. Párhuzamos szövegek számítógéppel segített elemzése a fordításoktatásban (2. rész). Fordítástudomány 2(1): 5-16.

Laviosa, Sara. 1998. Core patterns of lexical use in a comparable corpus of English narrative prose. Meta 43(4): 557-570. 
Mauranen, Anna. 2000. Strange strings in translated language. A study on corpora. In: Olohan, Maeve (ed.), Intercultural faultlines. Research models in translation studies I: Textual and cognitive aspects. Manchester: St. Jerome Pub. 119-141.

Mauranen, Anna-Kujamaki, Pekka (eds). 2004. Translation universals: do they exist? Amsterdam: Benjamins.

Olohan, Maeve-Baker, Mona. 2000. Reporting that in translated English: evidence for subconscious processes of explicitation? Across Languages and Cultures 1(2): 141-158.

Øverås, Linn. 1998. In search of the third code: an investigation of norms in literary translation. Meta 43(4): 571-588.

Pápai, Vilma. 2001. Az explicitációs hipotézis vizsgálata angol-magyar és magyar-magyar párhuzamos korpuszok egybevetésével. (Unpublished doctoral dissertation). PTE-SZIE, Pécs-Győr.

2004. Explicitation: a universal of translated text? In: Mauranen, AnnaKujamaki, Pekka (eds), Translation universals: do they exist?. Amsterdam: Benjamins. 143-164.

Pym, Anthony. 2008. On Toury's laws of how translators translate. In: Pym, AnthonyShlesinger, Miriam-Simeoni, Daniel (eds), Beyond descriptive translation studies: investigations in homage to Gideon. Amsterdam: John Benjamins. 311-328.

Rabadán, Rosa-Belén, Labrador-Ramón, Noelia. 2009. Corpus-based contrastive analysis and translation universals: a tool for translation quality assessment English $\rightarrow$ Spanish. Babel 55(4): 303-328.

Robin, Edina. 2015. Fordítási univerzálék a lektorált szövegekben. (Unpublished doctoral dissertation). ELTE, Budapest.

2016. Lektorált fordítások és eredeti magyar szövegek gépi összehasonlítása. Fordítástudomány 18(1): 19-30.

2017. Korpusznyelvészet és fordításkutatás: a Fordítástudományi Doktori Program korpusza. Elhangzott: XIV. Fordítástudományi PhD-konferencia. Budapest, ELTE BTK. (30 March 2017).

Robin, Edina-Szegh, Henriett. 2017. A Pannónia Korpusz audiovizuális korpusza. Elhangzott: Fordításoktatás - szakmai nap. Budapest, KRE BTK. (10 February 2017).

Saldanha, Gabriela-O’Brien, Sharon. 2012. Research methodologies in translation studies. Manchester: Routledge.

Scarpa, Federica. 2006. Corpus-based quality-assessment of specialist translation: a study using parallel and comparable corpora in English and Italian. In: Gotti, Maurizio-Sarcevic, Susan (eds), Insights into specialized translationlinguistics insights. Bern: Peter Lang. 155-172.

Seidl-Péch, Olívia. 2011. Fordított szövegek számítógépes összevetése. Autentikus magyar szövegek és fordítás eredményeként létrejött célnyelvi magyar szövegek 
lexikai kohéziós mintázatának összehasonlító elemzése. (Unpublished doctoral dissertation). ELTE, Budapest.

Shlesinger, Miriam-Ordan, Noam. 2012. More spoken or more translated? Exploring a known unknown of simultaneous interpreting. Target 24(1): 43-60.

Szabó Martina, Katalin-Schmalcz, András-Nagy T., István-Vincze, Veronika. 2011. A HunOr magyar-orosz párhuzamos korpusz. In: Tanács, Attila-Vincze, Veronika (eds), VIII. Magyar Számítógépes Nyelvészeti Konferencia. Szeged: JATEpress. 341-347.

Szegh, Henriett. 2016. Az audiovizuális alkorpusz létrehozásának módszertani kérdései. Elhangzott: A Papp Ferenc Baráti Kör Találkozója. Budapest, ELTE BTK FTT. (19 December 2016).

Szirmai, Mónika. 2005. Bevezetés a korpusznyelvészetbe. A korpusznyelvészet alkalmazása az anyanyelv és az idegen nyelv tanulásában és tanításában. Segédkönyvek a nyelvészet tanulmányozásához XLVI. Budapest: Tinta.

Tirkkonen-Condit, Sonja. 2002. Translationese - a myth or an empirical fact?: A study into the linguistic identifiability of translated language. Target 14(2): 207-220.

2004. Unique items - over- or under-represented in translated language? In: Mauranen, Anna-Kujamaki, Pekka (eds), Translation universals: do they exist? Amsterdam: Benjamins. 177-186.

Toury, Gideon. 1995. Descriptive translation studies and beyond. Amsterdam: Benjamins.

Tymoczko, Maria. 1998. Computerized corpora and the future of translation studies. Meta 43(4): 653-659.

Xiao, Richard-He, Lianzhen-Yue, Ming. 2010. In pursuit of the third code: Using the ZJU corpus of translational Chinese in translation studies. In: Xiao, Richard (ed.), Using corpora in contrastive and translation studies. Newcastle: Cambridge Scholars Publishing. 182-214.

Zanettin, Federico. 2000. Parallel corpora in translation studies: Issues in corpus design and analysis. In: Olohan, Maeve (ed.), Intercultural faultlines. Research models in translation studies I: Textual and cognitive aspects. Manchester: St. Jerome Pub. 105-118.

2011. Translation and corpus design. SYNAPS - A Journal of Professional Communication 26: 14-23. 